\title{
Lokal iskemi kan oppdages ved intraorgan $\mathrm{CO}_{2}$-måling
}

\author{
Ved redusert blodtilførsel stiger vevs- $\mathrm{CO}_{2}$. Ved hjelp av nyutviklede \\ $\mathrm{CO}_{2}$-sensorer plassert i truede organer kan man oppdage iskemi \\ tidligere enn med dagens kliniske monitoreringsutstyr.
}

Stenose av blodkar til organer i det perioperative forløpet ved store operasjoner som hjerte- eller leverkirurgi fører til iskemisk celleskade og i verste fall død. Slik iskemi er vanskelig å diagnostisere og blir derfor ofte først oppdaget når celleskaden er irreversibel. $\mathrm{CO}_{2}$-nivået øker lokalt når blodgjennomstrømmingen avtar - tidlig på grunn av stagnasjon av aerobt produsert $\mathrm{CO}_{2}$ og senere når cellemetabolismen skifter fra aerob til anaerob metabolisme, da laktacidosen bufres av bikarbonat og danner $\mathrm{CO}_{2}$. En ny, norskutviklet miniatyrsensor, IscAlert, med diameter $0,7 \mathrm{~mm}$, måler vevspartialtrykk av $\mathrm{CO}_{2}\left(\mathrm{PtCO}_{2}\right)$ i sanntid, men denne er ikke blitt undersøkt $\mathrm{i}$ indre organer.

Alle studiene i doktoravhandlingen var eksperimentelle studier i gris. Myokardialt $\mathrm{CO}_{2}$-nivå økte signifikant som følge av total eller delvis okklusjon av koronararterier, og sensoren detekterte det iskemiske området med høy sensitivitet og spesifisitet. $\mathrm{CO}_{2}-$ sensorer i lever detekterte økende $\mathrm{CO}_{2}-$ nivåer ved stenose av a. hepatica, mens intraabdominale $\mathrm{CO}_{2}$-sensorer detekterte vena porta-okklusjon og tarmiskemi. Økende $\mathrm{PtCO}_{2}$-nivå korrelerte med avtakende cellefunksjon, økt anaerobt stoffskifte, synkende $\mathrm{pH}$ og celleskade.

$\mathrm{PtCO}_{2}$-måling gjør det mulig å bestemme med én gang hvilket blodkar som er blokkert. Ved bruk av slike målinger kan videre diagnostikk og behandling starte raskere enn før, og pasienten kan ha større sjanse for å overleve uten varige skader. $\mathrm{PtCO}_{2}-$ måling er et lovende nytt prinsipp for pasientovervåking. Studier i utvalgte pasientgrupper er planlagt.

\section{Søren Erik Pischke}

s.e.pischke@medisin.uio.no

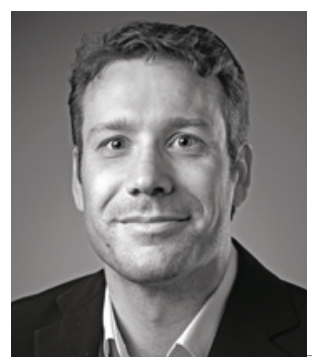

Søren Erik Pischke. Foto: Kristin Ellefsen

\section{Disputas}

Søren Erik Pischke disputerte for ph.d.-graden ved Universitetet i Oslo 29.4. 2015. Tittelen på avhandlingen er Tissue $\mathrm{PCO}_{2}$ for real-time detection of internal organ ischemia.

\section{Tilfeldig depresjonsbehandling i sykehjem}

\section{Depresjon er utbredt blant sykehjemspasienter, men både depresjons- diagnostikk og depresjonsbehandling er tilfeldig.}

Depresjon er forbundet med økt morbiditet og økt mortalitet og gir nedsatt livskvalitet hos allerede skrøpelige sykehjemspasienter. Vi vet imidlertid lite om helsepersonellets håndtering av depresjon hos pasientene og om pasientenes egen persepsjon av tristhet.

Avhandlingen er basert på tre empiriske studier. Vi gjennomførte en klinisk studie, der vi kartla forekomst, diagnostikk og behandling av depresjon hos nyinnlagte sykehjemspasienter. I en fokusgruppestudie utforsket vi legers og sykepleieres beslutningsgrunnlag for å starte, evaluere og avslutte depresjonsbehandling i sykehjem. Deretter belyste vi sykehjemspasienters tanker om egen tristhet $i$ en kvalitativ intervjustudie.

Vi fant at depresjon og tristhet er vanlig blant sykehjemspasienter. Depresjonsdia- gnostikken er tilfeldig, og halvparten av pasientene får medikamentell behandling selv om leger og sykepleiere er usikre på behandlingseffekten. Pasientene savnet samtaler med personalet når de følte seg triste. Sykepleierne på sin side anerkjente ulike miljøtiltak, men hadde som oftest ikke tid til å gjennomføre slike.

Funnene våre viser at leger og sykepleiere bør være mer bevisst på depresjonsdiagnostikk og depresjonsbehandling i sykehjem. Medikamentelle og ikke-medikamentelle behandlinger bør evalueres regelmessig. Leger og sykepleiere bør støtte opp under pasientens egne mestringsressurser.

\section{Kristina Riis Iden}

kristina.idenđagmail.com

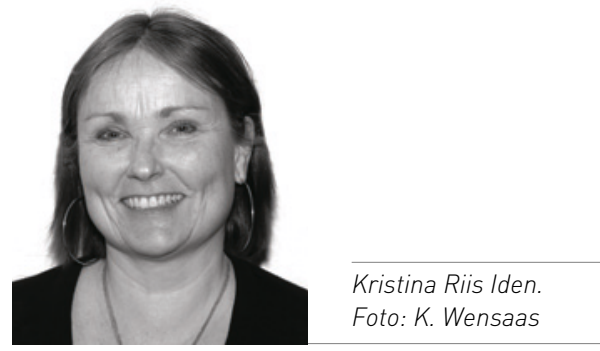

Disputas

Kristina Riis Iden disputerte for ph.d.-graden ved Universitetet i Bergen 29.4. 2015. Tittelen på avhandlingen er Depresjon i sykehjem. Underdiagnostikk og overbehandling. 